\title{
Is Additional Cardiac Procedure A Catastrophic Risk During Bentall Operation? Long Term Results in A Tertiary Center
}

\author{
İsmail Haberal ${ }^{1}$, Mehmet Ali Yesiltas ${ }^{2 *}$ and Kürșad Öz ${ }^{3}$ \\ ${ }^{1}$ Department of Cardiovascular Surgery, Istanbul University-Cerrahpasa Institute of Cardiology, Istanbul, Turkey \\ ${ }^{2}$ Department of Cardiovascular Surgery, Bakırköy Dr.Sadi Konuk Training and Research Hospital, Istanbul, Turkey
}

${ }^{3}$ Department of Cardiovascular Surgery, University of Health Sciences Istanbul Mehmet Akif Ersoy Thoracic and Cardiovascular Surgery Training and Research Hospital, Istanbul, Turkey

Submission: February 10, 2021; Published: February 26, 2021

*Corresponding author: Mehmet Ali YEŞiLTAȘ, Consultant, Department of Cardiovascular Surgery Bakırköy Dr.Sadi Konuk Training and Research Hospital, Istanbul, Turkey

Abstract

Background: The aim of this study was to assess the influences of concomitant cardiac surgery on the risk for mortality and morbidity after Bentall procedure.

Material- Methods: This retrospective study was a review of patients who underwent Bentall procedure from a single center experience over a 7-year period. Demographic features, surgical data, postoperative period and outcomes were analyzed. Patients with isolated Bentall surgery (Group A) were compared and concomitant cardiac surgery with Bentall procedure were compared (Group B).

Results: Of 232 patients, 207 (89.2\%) included in our study. There were 144 patients in Group A and 63 in Group B. Patients with bicuspid valve, low left ventricular systolic function, high Euroscore and those aged 65 years and older were significantly higher in Group B. Considering surgical data and postoperative period, bypass time, in-hospital red blood cell and apheresis transfusion, postoperative creatinine were statistically different in Group B ( $\mathrm{p}<0.05)$. Likewise, in addition to requirement of inotropic support and postoperative drainage volume were found to be statistically different, whereas other surgical factors did not vary significantly. The overall patient survival was $88.4 \%$ at the mean follow-up of 72.4 \pm 8.8 months (3-92 months). The overall patient survival was $88.4 \%$ at the mean follow-up of 72.4 \pm 8.8 months (3-92 months). In-hospital death occurred in ten (4.8\%) patient in both group $(4,2.8 \%$ vs $6,9.5 \%$, respectively, $\mathrm{p}<0.01)$.

Conclusion: This study highlighted that concomitant cardiac surgery with Bentall procedure can be safely performed with acceptable morbidity and mortality rates.

Keywords: Aortic operation; Complications; Outcomes

\section{Introduction}

Since Bentall procedure for composite aortic valve and root replacement with reimplantation of the coronary arteries was first described in 1968 [1], various adaptations for pathologic conditions involving the ascending aorta and aortic valve have been reported [2-5]. Although excellent results have been reported after this complex procedure in elective patients, overall mortality in some series is around 10\% [5-9]. In some patients planned for Bentall procedure, concomitant cardiac surgical procedures such as coronary artery bypass grafting, valve replacement/repair for the other valve abnormalities (mitral, tricuspid, etc.) or ablation procedure using unipolar catheter for cardiac arrhythmias are required to be performed.
Despite its decreasing surgical risk factors, we wonder if additional procedures increase the mortality and morbidity rates in patients underwent Bentall procedure. In this report, we presented early results of our experience in Bentall operation to determine whether additional surgical procedures with aortic root replacement could be contributing factor to a higher rate of morbidity and/or mortality in the postoperative period.

\section{Material- Methods}

This retrospective study was approved by the Local Ethics Committee and a waiver of informed consent was obtained. Between June 2009 and March 2016, all patients who underwent 
Bentall procedure (aortic root replacement for an aortic root aneurysm) at state hospital, Department of Cardiovascular Surgery were analyzed and perioperative data were collected from patient medical records. Those patients with degenerative and/or atherosclerotic aneurysm with aortic valve insufficiency were included in the study. The exclusion criteria were as follows: acute type A dissection, traumatic or iatrogenic aortic rupture, infective endocarditis and the patients with previous history of cardiac surgery (coronary bypass, valve repair or other cardiac procedures). Those patients with valve-preserving aortic root reconstruction were also not involved. Data were collected by chart review. Follow-up data were obtained by re-examining the patients in our follow-up clinic and phone call was made with surviving patients or their relatives. Echocardiographic data were obtained for $116(80.6 \%)$ patients at follow-up.

All of the operations in this series were performed by a single surgical team (I.B). All patients except one (168 male, 39 female) underwent a composite valve conduit reconstruction (192 mechanical valve, 15 bioprosthetic valve. All patients were divided into 2 groups according to the operative procedures; Group A included the patients who were performed isolated Bentall procedure and Group B consisted of the patients performed concomitant procedures with Bentall operation (coronary artery bypass surgery, valve placement or repair, ablation procedures and other cardiac procedures). Postoperative morbidity and mortality were compared between two groups, considering the operative procedure.

Data examined comprised (1) demographics, (2) aortic characteristics such as diameter of ascending aort, (3) ejection fraction, (4) native valve pathology, (5) details of the surgical therapy (including operating time, bypass time, cross-clamp time, hemofiltration, etc.), (6) transfusion of blood products (red blood cells (RBC), fresh frozen plasma (FFP) and platelets) and postoperative laboratory findings, (7) intensive care unit (ICU) course (ventilator support time, requirement for inotropic support, length of ICU stay, (8) hospital course (including complications, hospital stay ), (9) survival, and (10) follow-up examinations. All deaths occurring within 30 days after surgery or within the same hospital admission were classified as in-hospital mortality.

\section{Statistical Analysis}

All categorical variables are expressed as percentages, and continuous variables are expressed as means \pm standard deviation (SD). Categorical variables were compared using either Pearson's chi-squared test, chi-square with Yates' correction for continuity or Fisher's exact tests, and continuous variables were compared using Student's test for normally distributed or the Mann-Whitney U-test for non-normally distributed data where appropriate. Values of $\mathrm{p}<0.05$ were considered to indicate statistical significance. All analyses were carried out using SPSS software, version 17 (SPSS, Chicago, IL, USA)

\section{Surgical procedure}

A median sternotomy approach is used in all cases. Cannulation sites of groups for extra-corporeal circulation (ECC) are shown in Table 1. Cardiopulmonary bypass (CPB) is mostly established with right femoral arterial-venous cannulation for those underwent concomitant cardiac procedures with Bentall procedure (Group B) or single venous cannulation through the right atrium for venous return for the patients performed isolated Bentall procedure (Group A). After classic modified Bentall operation with the button technique was employed, if surgical adhesive is needed, BioGlue ${ }^{\circledR}$ (Cryolife, Inc., Kennesaw, GA, USA) is routinely used to secure homeostasis and reinforce weak tissues in the surgical site. In Group B, mitral valve repair/replacement is performed via Guiraudon incision as it is extensively described in a previous report [10]. Additionally, in the patients in whom surgical treatment of atrial fibrillation is planned, our specific strategy that is applied has been documented in a review article published before [11].

Table 1: Cannulation sites for ECC in both groups.

\begin{tabular}{|c|c|c|}
\hline Access; n, \% & $\begin{array}{c}\text { Group A } \\
(\mathbf{n = 1 4 4})\end{array}$ & $\begin{array}{c}\text { Group B } \\
(\mathbf{n = 6 3})\end{array}$ \\
\hline Femoral artery & $82(56.9)$ & $29(46)$ \\
\hline Ascending Aorta & $42(29.2)$ & $21(33.3)$ \\
\hline Ascending aorta +Axillary artery & $14(9.7)$ & $13(20.6)$ \\
\hline Right atrium & $80(55.6)$ & $30(47.6)$ \\
\hline Bicaval & $24(16.7)$ & $6(9.5)$ \\
\hline Femoral vein & $8(5.6)$ & $12(19)$ \\
\hline Femoral vein + SVC & $28(19.4)$ & $15(23.8)$ \\
\hline Femoral vein + IJV & $4(2.7)$ & $3(4.7)$ \\
\hline ECC, extra-corporeal circulation; IJV, internal jugular vein; SVC, superi- \\
or vena cava \\
\hline
\end{tabular}

\section{Results}

During study period, 232 patients underwent Bentall procedures. With regards to the exclusion criteria defined in methods section, only 207 patients (168 male, 39 female) with a mean age of $54.9 \pm 12.4$ (range, $31-74$ ) years (mean \pm SD) were enrolled in this study. Eight patients $(3,9 \%)$ had clinical stigmata of Marfan's syndrome. Group A included 142 patients who underwent isolated Bentall procedure while the patients undergoing concomitant cardiac procedures with Bentall surgery were evaluated in Group B $(n=63)$. Demographic variables between two groups were detailed in Table 2. Group A and B did not differ according to gender, co-morbidity rates and diameter of aorta. In group B, patients with $\geq 65$ years old, bicuspid valve, $\mathrm{EF} \leq 45 \% \%$ and Euroscore were significantly higher compared to Group A. In fact, Euroscore was the most important determinant factor of concomitant surgery with Bentall operation ( $p=0,0001$, 


\section{Journal of Cardiology \& Cardiovascular Therapy}

CI:4,45-76,92). Preoperative aortic valve indication for surgery and pathology of the aortic valve were detailed in Table 3. Aortic root reconstruction using composite mechanical $(n=192)$ or stented bioprosthetic valved $(n=15)$ conduits was performed according to the age at the time of operation or patients' choice during the preoperative interview with the patients. There were 66 patients (31.9\%) aged over 65 years.

Table 2: Demographic variables and laboratory findings.

\begin{tabular}{|c|c|c|c|}
\hline Parameters & Group A $(n=144)$ & Group B $(n=63)$ & $\mathbf{p}$ \\
\hline Sex (male/female) & $108 / 36$ & $60 / 3$ & 0.06 \\
\hline Age $($ mean $\pm S D)$ (years) & $52.8 \pm 12.5$ & $60 \pm 10.8$ & 0.21 \\
\hline$\geq 65$-year old, n(\%) & $36(25)$ & $30(47.6)$ & 0.02 \\
\hline EuroSCORE & $1.4 \pm 0.5$ & $3.4 \pm 0.8$ & $<0.01$ \\
\hline Body surface area (mean \pm SD) & $1.84 \pm 0.1$ & $1.82 \pm 0.1$ & 0.47 \\
\hline Diameter of ascending aorta, $($ mean \pm SD) $(\mathrm{mm})$ & $52.7 \pm 5.5$ & $54 \pm 7.1$ & 0.44 \\
\hline Bicuspid valve, $n(\%)$ & $68(47.2)$ & $9(14.3)$ & 0.02 \\
\hline Ejection fraction $\leq 45 \%, \mathrm{n}(\%)$ & $12(8.3)$ & $30(47.6)$ & $<0.01$ \\
\hline \multicolumn{3}{|c|}{$\begin{array}{c}\text { Comorbidity, } \mathrm{n}(\%) \\
56(38.9) \\
39(61.9)\end{array}$} & 0.56 \\
\hline \multicolumn{4}{|c|}{ Laboratory results (mean $\pm S D)$} \\
\hline Preoperative hematocrite (\%) & $41 \pm 5.2$ & $38.9 \pm 9,3$ & 0.27 \\
\hline Preoperative creatinine (mg/dl) & $0.8 \pm 0.2$ & $0.9 \pm 0.1$ & 0.65 \\
\hline Postoperative hematocrite (\%) & $29.6 \pm 4.2$ & $29.3 \pm 2.7$ & 0.75 \\
\hline Postoperative creatinine (mg/dl) & $1.0 \pm 0.4$ & $1.4 \pm 0.6$ & 0.01 \\
\hline Hospital stay (mean \pm SD) (days) & $11.2 \pm 9.7$ & $9.7 \pm 3.4$ & 0.18 \\
\hline Prolonged hospital stay, n(\%) & $8(5.6)$ & $2(3.2)$ & 0.39 \\
\hline
\end{tabular}

Table 3: Preoperative aortic valve characteristics.

\begin{tabular}{|c|c|c|}
\hline \multicolumn{2}{|c|}{ Group A (n=144) } & Group B(n=63) \\
\hline \multicolumn{1}{|c|}{ Valve Indication (n,\%) } & $116(80.6)$ & $48(76.2)$ \\
\hline Insufficiency & $16(11.1)$ & $6(9.5)$ \\
\hline Stenosis & $12(8.3)$ & $9(14.3)$ \\
\hline Mixed & Valve Pathology (n,\%) & $3(4.8)$ \\
\hline Rheumatic & $8(5.6)$ & $45(71.4)$ \\
\hline Degenerative & $60(41.7)$ & $6(9.5)$ \\
\hline Bicuspid (congenital) & $68(47.2)$ & $9(14.3)$ \\
\hline Other & $8(5.5)$ & \\
\hline
\end{tabular}

Surgical data \& blood transfusions: The cardiac surgical procedures concomitant with Bentall in Group B were summarized in Table 4. Cardiopulmonary bypass time was significantly higher in Group B ( $\mathrm{p}=0.02)$. Hemofiltration during CPB was performed for $141(68.1 \%$ ) patients with a mean volume of $1704.16 \pm 645.73$; 112 patients in Group A and 58 patients in Group B (p=0.46; $77.8 \%$ vs. $92.1 \%$, respectively). The mean number of transfused RBC during hospital stay was $6.0 \pm 3.7$ units. The number of RBC units transfused were statistically significantly higher in Group B compared to Group A (5.08 \pm 2.7 unit vs. 7.7 \pm 4.6 unit, respectively, $\mathrm{p}<0.01)$. Requirement of PRBC during the postoperative period was required for 146 patients (70.5\%); 92 patients in Group A $(63.9 \%)$ and 54 patients in Group B (85.7\%) ( $p=0.45)$. Transfusion of platelet products was also significantly higher in Group B.

Postoperative complications: Postoperative creatinin levels, drainage volume and postoperative requirement of inotropic support were also statistically different between groups $(\mathrm{p}=0.01$, $\mathrm{p}=0.03$ and $<0.01$, respectively). Detailed data related to surgery 


\section{Journal of Cardiology \& Cardiovascular Therapy}

and postoperative period are shown in Table 5. There was no patient with peripheral vascular complication due to cannulation site problem. In five patients in Group B, a reoperation for bleeding was required. The source of bleeding was the proximal anastomotic site in one patient (reoperated twice) whereas no obvious bleeding source was found in the other. Three patients in Group A required urgent surgical reintervention for pericardial effusion and subsequent tamponade in the first postoperative month. Placement of pericardial drainage tube was performed through a small subxiphoid incision for both patients. No further complication was observed. Regarding the postoperative conduction disturbances, postoperative atrial fibrillation was diagnosed in 25 patients (12.1\%) and converted to sinus rhythm before hospital discharge. Two patients required permanent pacemaker.

Table 4: Concomitant cardiac surgical procedures in Group B $(n=63)$.

\begin{tabular}{|c|c|c|}
\hline Operation & $\mathrm{n}$ & $\%$ \\
\hline $\mathrm{CABG}$ & 45 & 71.4 \\
\hline Mitral valve ring annuloplasty & 7 & 11.1 \\
\hline $\mathrm{CABG}+$ mitral valve ring annuloplasty* & 6 & 9.5 \\
\hline Mitral valve replacement+ Tricuspid ring valvuloplasty & 3 & 4.8 \\
\hline Left atrial reduction+/- Ablation procedure, LAA ligation & 2 & 3.2 \\
\hline \multicolumn{3}{|c|}{$\begin{array}{l}\text { CABG: coronary artery bypass grafting, } \\
\text { ents had also carotid surgery before the main surgical procedure }\end{array}$} \\
\hline
\end{tabular}

Table 5: Surgical data and postoperative complications.

\begin{tabular}{|c|c|c|c|}
\hline & Group A (n=144) & Group B $(n=63)$ & $\mathbf{p}$ \\
\hline \multicolumn{4}{|c|}{ Operative details (mean \pm SD) } \\
\hline $\mathrm{x}$-clamp time(minutes) & $187.9 \pm 43.2$ & $234.3 \pm 49.1$ & 0.43 \\
\hline Bypass time(minutes) & $224.8 \pm 42$ & $290.0 \pm 67.3$ & 0.02 \\
\hline $\mathrm{HF}$ volume during $\mathrm{CPB}(\mathrm{ml})$ & $1316.6 \pm 814.6$ & $1638.31 \pm 882.3$ & 0.82 \\
\hline Drainage (ml) (mean \pm SD) & $765.2 \pm 514.8$ & $1138 \pm 689.9$ & 0.03 \\
\hline $\begin{array}{l}\text { Requirement of PRBC (patient number) (postoperatively) (mean } \\
\text { unit } \pm \text { SD) }\end{array}$ & $92(63.9 \%)$ & $54(85.7 \%)$ & 0.45 \\
\hline PRBC (total) & $5.08 \pm 2.7$ & $7.7 \pm 4.6$ & $<0.01$ \\
\hline PRBC (postoperative) & $1.9 \pm 1.4$ & $2.7 \pm 2.3$ & 0.09 \\
\hline FFP & $3.5 \pm 2.8$ & $2.4 \pm 3.4$ & 0.21 \\
\hline Platelet transfusion (random or apheresis)* & $2.0 \pm 2.5$ & $5.0 \pm 3.5$ & $<0.01$ \\
\hline Postoperative complications, $n, \%$ & $35(24.3 \%)$ & $38(60.3 \%)$ & $<0.01$ \\
\hline Atrial fibrillation \& other rhythm disorders & 15 & 10 & \\
\hline Requirement for pacemaker $* *$ & 4 & 2 & \\
\hline Respiratory system & 6 & 7 & \\
\hline Renal complication & 3 & 6 & \\
\hline Pericardial effusion require intervention & 3 & 3 & \\
\hline Infective complication & 2 & 2 & \\
\hline Re-operation for bleeding & 3 & 5 & \\
\hline Sternal dehiscence/infection & 1 & 2 & \\
\hline Surgical site infection & 2 & 3 & \\
\hline Inotropic support, n (\%) & 27 (18.8) & $12(57.1)$ & $<0.01$ \\
\hline Prolonged length of intensive care unit & $38(26.3)$ & $26(41.3)$ & 0.39 \\
\hline Prolonged intubation time & $16(25.4)$ & $15(23.8)$ & 0.44 \\
\hline
\end{tabular}




\begin{tabular}{|c|c|c|c|c|}
\hline \multicolumn{2}{|c|}{ Follow-up (mean \pm SD) (months) } & $70.4 \pm 9.9$ & $61.0 \pm 10.5$ & 0.84 \\
\hline \multirow{3}{*}{ Mortalitył, n (\%) } & $\begin{array}{l}\text { Early } \\
<30 d\end{array}$ & $4(2.8)$ & $6(9.5)$ & $<0.01$ \\
\hline & $\begin{array}{l}\text { Late } \\
>30 \mathrm{~d}\end{array}$ & $8(5.6)$ & $5(7.9)$ & 0.43 \\
\hline & $\begin{array}{c}\text { All mor- } \\
\text { tality }\end{array}$ & $12(8.3 \%)$ & $11(17.5 \%)$ & $<0.01$ \\
\hline \multicolumn{5}{|c|}{$\begin{array}{l}\text { *one unit of platelets apheresis equals “6/7 pack" of pooled platelets } \\
\qquad * \text { transient pacemaker postoperative early period, } \\
\text { ‡ only cardiac-related late mortality was evaluated } \\
\text {, cardiopulmonary bypass; PRBC, packed red blood cells; FFP, Fresh frozen plasma; SD, standard deviation l }\end{array}$} \\
\hline
\end{tabular}

Hospital stay: The mean hospital stay was $10.5 \pm 8.4$ days (range: 5-56 days) and 10 (4.8\%) patients (8 in group A and 2 in group B) had prolonged length of hospital stay ( $\geq 14$ days). Neither mean hospital stay $(p=0.18)$ nor prolonged hospital stay was significantly different between two groups $(\mathrm{p}=0.39)$.

Follow-up\& mortality: The overall patient survival was 88.4 $\%$ at the mean follow-up of $72.4 \pm 8.8$ months (3-92 months). The operative mortality was none. In-hospital death occurred in ten (4.8\%) patient in both group $(4,2.8 \%$ vs $6,9.5 \%$, respectively, $\mathrm{p}<0.01$ ). One patient died on the postoperative day 13 probably as a result of toxicity from amiodarone treatment and subsequent multiorgan failure. In the follow-up period, nine patients (16\%) died. Patients who died from other non-cardiac causes (one traffic accident and the other following orthopedic surgery) were excluded from analysis. After then, mortality rates for late period were found no significant between groups $(p=0.43)$. However, in group B, a 2,5-fold increase (CI:0.519 - 12.92) in risk for all-cause mortality was detected. Of 13/207 late operation-related deaths (6.3\%), four patients died secondary to cerebrovascular accident, two died of congestive heart failure, one died of a ruptured false aneurysm at the proximal anastomotic site and one died of an unknown cause elsewhere. Two patients suffered from respiratory failure and died due to severe sepsis in the postoperative month in our critical care unit. Four patients was found dead in bed and we were informed by phone call from relatives. During follow-up, Three patients (1.4\%) required reoperation because of infective complications One patient suffered from spreading on composite graft and developing a pseudoaneurysm. He was taken emergency operation but he died after operating in early period. Two patients suffered endocarditis, but survived without surgical treatment.

\section{Discussion}

As a result of the increasing age of patients requiring Bentall surgery, preexisting coronary artery disease or other heart valve disorders have been increasingly diagnosed among the patients presenting with aneurysm of ascending aorta. In addition, because elective coronary bypass graft or valve surgery can be performed with success rates approaching 98\%, cardiac surgeons have been encouraged to perform other cardiac procedures concomitantly. However, the influence of concomitant cardiac procedures on outcome of Bentall procedure remains unclear despite some reports indicating increased mortality rates in these patient populations [12]. Our study compares the outcome of Bentall patients from a single center experience regarding whether concomitant surgical procedure is performed or not. The size of the cohort allows meaningful comparison of factors affecting outcome.

According to published reports, incidence for concomitant cardiac surgery has been variously quoted as between $4 \%$ and $40 \%$. In almost all, CABG is the most common surgical procedure with a rate of $3 \%$ up to $20 \%$ [13-16]. In our study, the incidence of $30.4 \%$ for concomitant cardiac procedures is in accordance with those previously reported and CABG was also the most frequently performed concomitant cardiac procedure with a rate of $21.7 \%$.

Theoverall morbidity rate was higher in thosewith concomitant surgery ( $24.3 \%$ vs $60.3 \%$ ), it was statistically significant between two groups $(\mathrm{p}<0.01)$. This is thought to be related with preexisting medical comorbidities ( $\geq 50 \%)$ and higher incidence of patients aged $\geq 65$ years in addition to higher EuroSCORE and low EF rate. Undoubtedly, there were also postoperative parameters that affect this postoperative course. In previously published reports, long CPB time and aortic x-clamp times, left ventricular ejection fraction $<35 \%$, aortic dissection, and concomitant coronary artery bypass disease were among the factors that adversely affect the development of postoperative morbidity [12]. In our study, those with concomitant surgery to Bentall had longer CPB time, lower $\mathrm{EF}$ values, higher drainage volume and subsequent requirement of RBC transfusion. This should not be underestimated that these patients requiring high-complex surgery usually have poorer health status and suffer worse outcome.

One of the most significant complications documented for Bentall patients is associated with composite graft, requiring reoperation in $0-3.7 \%$ of reports $[3,8,17,18]$. Interestingly, Yacoub et al. reported higher rate of reoperation $(11 \%)$ in their study including patients with valve preserving operation for ascending aorta aneurysm [19]. In the follow-up period, three patients $(1.4 \%)$ presenting with sepsis due to deep sternal wound infection required reoperation. Intraoperative findings revealed false aneurysm of the aorta probably secondary to infection 
spreading directly to the composite graft. This rare complication is usually represent with septic complications and carry high risk of morbidity and mortality reaching $40 \%$ [20].

We encountered valve-related complications such as endocarditis in only two patients while Gott et al. reported endocarditis as the most common late complication (5.4\%) that mitral valve repair was the most frequently performed concomitant procedure in their study providing a difference from most reports [21]. While no patient suffered valve thrombosis, one patient was administered antibiotics due to suspicious signs of infective endocarditis and treated without surgery. Prifti, et al. also reported renal system complications as the most commonly seen in the postoperative period [22]. In our study, postoperative creatinine levels were statistically higher in group B. Other postoperative complications were similar to previous reports $[5,22]$.

Mortality rates reported for a wide range of patient populations with ascending aortic aneurysm, considering different surgical procedures or materials, have been up to $20 \%[5,7,16]$. Over the last two decades, thirty-day mortality/in-hospital mortality for aortic root replacement has fallen from 13,8 to below 5\% $[21,23,24]$. Savunen et al. reported a $3 \%$ early mortality in 100 patients undergoing a modified Bentall procedure with no anastomotic problems in the follow-up period [25]. In our study, results with a rate of $4.8 \%$ for in-hospital mortality in all patients compare favorably with the published literature. Several factors such as emergent operation, older age, preoperative health status, aortic dissection, concomitant coronary artery bypass grafting, low left ventricular ejection fraction, prolonged bypass time have been reported as predictors of early death [16,21-23]. Fortunately, one patient who was the only in-hospital mortality in Group B died due to the reasons other than stated above. Late mortality rates from Bentall have been reported in a wide range. Because, our cardiovascular center is quite new, just for three years, we could not provide 3 and 5-year survival rate but available outcome is compatible with the other most studies. Five-year survival rate of 73 to $92 \%$, being 60 to $73 \%$ at 10 years is also shown by several studies [3,26-29]. In our study, late mortality with a rate of $12.5 \%$ is in keeping with those previously reported [3,5,21,24,30,31]. Analyzing the causes of late deaths; only 7 patients of 56 hospital survivors died of plausible operation-related factors as explained in detail in results section ( 2 with non-cardiac causes). Between groups according to the surgical procedure, no difference was observed with regard to mortality rate.

One limitation of this study is retrospective, nonrandomized and single center study. Secondly, we only enrolled the elective patients, emergency was considered as a risk factor for morbidity and/or mortality.

In conclusion; despite an increasing probability of poor outcome, our results pointed out that concomitant surgical interventions with Bentall procedure can be safely performed at our cardiac surgery center. Further studies with larger sample sizes may be important for elucidating the role of concomitant surgery in outcome of Bentall surgery.

\section{References}

1. Bentall H, De Bono A (1968) A technique for complete replacement of the ascending aorta. Thorax 23(4): 338-339.

2. Grey DP, Ott DA, Cooley DA (1983) Surgical treatment of aneurysm of the ascending aorta with aortic insufficiency. J Thorac Cardiovasc Surg 86(6): 864-877.

3. Lewis CT, Cooley DA, Murphy MC, Talledo O, Vega D (1992) Surgical repair of aortic root aneurysms in 280 patients. Ann Thorac Surg 53(1): 38-45.

4. Cabrol C, Pavie A, Gandjbakhch I, Villemot JP, Guiraudon G, et al. (1981) Complete replacement of the ascending aorta with reimplantation of the coronary arteries: new surgical approach. J Thorac Cardiovasc Surg 81(2): 309-315.

5. Kouchoukos NT, Wareing TH, Murphy SF, Perrillo JB (1991) Sixteenyear experience with aortic root replacement: results of 172 operations. Ann Surg 214(3): 308-318.

6. Baumgartner WA, Cameron DE, Redmond JM, Greene PS, Gott VL (1999) Operative management of Marfan syndrome: The Johns Hopkins experience. Ann Thorac Surg 67: 1859-1860.

7. Aoyagi S, Kosuga K, Akashi H, Oryoji A, Oishi K (1994) Aortic root replacement with a composite graft: results of 69 operations in 66 patients. Ann Thorac Surg 58(5): 1469-1475.

8. Svensson LG, Crawford ES, Hess KR, Coselli JS, Safi HJ (1992) Composite valve graft replacement of the proximalaorta: comparison of techniques in 348 patients. Ann Thorac Surg 54(3): 427-437.

9. Ehrlich MP, Ergin MA, McCullough JN, Lansman SL, Galla JD, et al. (2000) Favorable outcome after composite valve-graft replacement in patients older than 65 years. Ann Thorac Surg 71(5): 1454-1459.

10. Bakir I, Guiraudon GM, Wellens F (2007) Surgical treatment of WolffParkinson-White syndrome: a timeless procedure? Acta Cardiol 62(2): 207-209.

11. Bakir I, Casselman FP, Brugada P, Geelen P, Wellens F, et al. (2007) Current strategies in the surgical treatment of atrial fibrillation: review of the literature and Onze Lieve Vrouw Clinic's strategy. Ann Thorac Surg 83(1): 331-340.

12. Ghavidel AA, Tabatabaei MB, Yousefnia MA, Omrani GR, Givtaj N, et al. (2006) Mortality and Morbidity After Aortic Root Replacement: 10Year Experience. Asian Cardiovasc Thorac Ann 14(6): 462-466.

13. Baraki H, Al Ahmad A, Sarikouch S, Koigeldiev N, Khaladj N, et al. (2010) The first fifty consecutive Bentall operations with a prefabricated tissue-valved aortic conduit: a single-center experience. J Heart Valve Dis 19(3): 286-291.

14. Stewart AS, Takayama H, Smith CR (2010) Modified Bentall operation with a novel biologic valved conduit. Ann Thorac Surg 89(3): 938-941.

15. Djukanović B (2003) Replacement of the aortic root by compositegraft valve: Bentall procedure and its modifications. Acta Chir Iugosl 50(4): 47-51.

16. Cohn LH, Rizzo RJ, Adams DH, Aranki SF, Couper GS, et al. (1996) Reduced mortality and morbidity for ascending aortic aneurysm resection regardless of cause. Ann Thorac Surg 62(2): 463-468.

17. Ergin MA, Spielvogel D, Apaydin A, Lansman SL, McCullough JN, et al. (1999) Surgical treatment of the dilated ascending aorta: when and how? Ann Thorac Surg 67: 1834-1839; discussion 1853-1856. 
18. Niederhauser U, Kunzli A, Genoni P, Vogt P, Lachat M, et al. (1999) Composite graft replacement of the aortic root: long-term results, incidence of reoperations. Thorac Cardiovasc Surg 47(5): 317-321.

19. Yacoub MH, Gehle P, Chandrasekaran V, Birks EJ, Child A, et al (1998) Late results of a valve-preserving operation in patients with aneurysms of the ascending aorta and root. J Thorac Cardiovasc Surg 115(5): 1080-1090.

20. Fillmore AJ, Valentine RJ (2003) Surgical mortality in patients with infected aortic aneurysms. J Am Coll Surg 196(3): 435-441.

21. Gott VL, Gillinov AM, Pyeritz RE, Cameron DE, Reitz BA, et al. (1995) Aortic root replacement. Risk factor analysis of a seventeen-year experience with 270 patients. J Thorac Cardiovasc Surg 109(3): 536544

22. Prifti E, Bonacchi M, Frati G, Proietti P, Giunti G, et al. (2002) Early and long-term outcome in patients undergoing aortic root replacement with composite graft according to the Bentall's technique Eur J Cardiothorac Surg 21(1): 15-21.

23. Lytle BW, Mahfood SS, Cosgrove DM, Loop FD (1990) Replacement of the ascending aorta. Early and late results. J Thorac Cardiovasc Surg 99(4): 651-658.

24.Zehr KJ, Orszulak TA, Mullany CJ, Matloobi A, Daly RC, et al. (2004) Surgery for Aneurysms of the Aortic Root: A 30-Year Experience. Circulation 110(11): 1364-1371.
25. Savunen T, Inberg M, Niinikoski J, Rantakokko V, Vanttinen E (1996) Composite graft in annulo-aortic ectasia: nineteen years' experience without graft inclusion. Eur J Cardiothorac Surg 10(6): 428-432.

26. Darrin WD, Hallett J, Schaff H, Gayari M, Ilstrup D, et al. (1998) Improved prognosis of thoracic aortic aneurysms. JAMA 280(22): 1926-1929.

27. Juvonen T, Ergin MA, Galla JD, Lansman SL, Nguyen KH, et al. (1997) Prospective study of the natural history of thoracic aortic aneurysms. Ann Thorac Surg 63(6): 1533-1545.

28. Yakut C (2001) A new modified Bentall procedure: the flanged technique. Ann Thorac Surg 71(6): 2050-2052.

29. Shapira OZ, Aldea G, Cutter S, Fitzgerald C, Lazar H, et al. (1999) Improved clinical outcomes after operation of the proximal aorta: a 10-year experience. Ann Thorac Surg 67(4): 1030-1037.

30. Galloway AC, Colvin SB, LaMendola CL, Hurwitz JB, Baumann FG, et al. (1989) Ten-year operative experience with 165 aneurysms ofthe ascending aorta and aortic arch. Circulation 80 (3 Pt 1): I249-I256.

31. Crawford ES, Kirklin JW, Naftel DC, Svensson LG, Coselli JS, et al. (1992) Surgery for acute dissection of ascending aorta. J Thorac Cardiovasc Surg 104(1): 46-59.

Your next submission with Juniper Publishers
will reach you the below assets
- Quality Editorial service
- Swift Peer Review
- Reprints availability
- E-prints Service
- Manuscript Podcast for convenient understanding
- Global attainment for your research
- Manuscript accessibility in different formats
( Pdf, E-pub, Full Text, Audio)
- Unceasing customer service
Track the below URL for one-step submission
https://juniperpublishers.com/online-submission.php

